\title{
West Africa in the British Atlantic: trade, violence, and empire in the 1640s
}

Article

Accepted Version

Blakemore, R. J. (2015) West Africa in the British Atlantic: trade, violence, and empire in the 1640s. Itinerario, 39 (2). pp. 299-327. ISSN 0165-1153 doi: https://doi.org/10.1017/S0165115315000480 Available at https://centaur.reading.ac.uk/71911/

It is advisable to refer to the publisher's version if you intend to cite from the work. See Guidance on citing.

Published version at: https://www.cambridge.org/core/journals/itinerario/article/west-africa-in-the-british-atlantictrade-violence-and-empire-in-the-1640s/6395E206BA50E71E78EEAF0327ACD98A

To link to this article DOI: http://dx.doi.org/10.1017/S0165115315000480

Publisher: Cambridge University Press

All outputs in CentAUR are protected by Intellectual Property Rights law, including copyright law. Copyright and IPR is retained by the creators or other copyright holders. Terms and conditions for use of this material are defined in the End User Agreement.

www.reading.ac.uk/centaur

\section{CentAUR}

Central Archive at the University of Reading 
Reading's research outputs online 


\section{West Africa in the British Atlantic: Trade, Violence, and Empire in the 1640s}

Richard J. Blakemore

Note: This is the POST-PRINT version of an article published in Itinerario, vol. 39, issue 2 (August 2015), pp. 299-327, which has been published in final form at https://www.cambridge.org/core/journals/itinerario/article/west-africa-in-the-british-atlantictrade-violence-and-empire-in-the-1640s/6395E206BA50E71E78EEAF0327ACD98A. The page numbers of the published version have not been preserved; all references should therefore be made to the published version.

Abstract: The importance of Africa and African agency in the formation of the Atlantic world is now widely acknowledged by historians, but Africa has drawn less attention than other regions in analyses of the British Atlantic. Drawing upon the nascent methodology of global microhistory, this article contributes to a scholarly rebalancing by examining two maritime lawsuits from the 1640s concerning British voyages to Senegambia and Sierra Leone, both of which resulted in conflict between British seafarers and with their African trading partners. A close study of the documents surviving from these lawsuits provides an unusually detailed glimpse of these particular moments of contact and violence across cultures. More fundamentally, such an approach illuminates the ocean-spanning networks within which these ventures took place, and reveals the ways in which British traders and sailors perceived trade in Africa within their own legal frameworks. This article argues that by the middle of the seventeenth century, as merchants and politicans in Britain began to imagine an Atlantic empire, trade in West Africa was an important part of their vision of the Atlantic world.

Keywords: Atlantic world, Britain, Empire, Seafarers, West Africa

Affiliation and acknowledgements: Richard Blakemore is Lecturer in the History of the Atlantic world at the University of Reading. At the time of publication he was a Junior Research Fellow at Merton College, University of Oxford. He would like to thank the organizers and audiences of the British and Irish History Seminar, University of Cambridge, and the Blaydes House Maritime History Seminar, University of Hull, where sections of this article were presented, and the anonymous referees, Itinerario's editors, and Edmond Smith for their helpful comments and criticisms. 
During the early 1630s some English merchants sent off a ship to settle a new "plantation" on Kent Island in the Chesapeake Bay. ${ }^{1}$ This episode, a rather spectacular failure, seems to fit squarely into the story of British colonial expansion in the Americas: but it is the name of the ship — the Africa - that I take as my starting point. It might owe something to William Cloberry, an investor in the scheme who also participated in African commerce, but even if it was just a coincidence, it is an intriguing one. Ships and their voyages are strikingly emblematic of the relationships which constituted and characterised the Atlantic world, and the image of the Africa carrying these ill-fated European colonists across the ocean to America invites us to reconsider the connections between these continents and their significance during this early stage of British maritime expansion. ${ }^{2}$

British trade with Africa (especially West Africa) from the sixteenth century onwards has been researched in detail by a number of scholars. ${ }^{3}$ In analyses of the British Atlantic, however, Africa has drawn less attention than other regions. "The British Atlantic world was mostly a black Atlantic world," Trevor Burnard has written, but "Africa remains to be fully incorporated into British Atlantic history." 5 This is all the more problematic given the widespread consensus that Africa, and African agency, was key to the development of early modern Atlantic commercial and cultural exchanges. ${ }^{6}$

\footnotetext{
${ }^{1}$ Marsden and Semmes, "Claiborne vs. Cloberry"; Roper, "Charles I," 40-4; O’Riordan, Plundering Time; Blakemore, "London and the Thames Maritime Community," 227-39. ${ }^{2}$ On ships as emblems, see Gilroy, Black Atlantic, 4; Boelhower, "'I'll Teach You How to Flow."

${ }^{3}$ The best overview is Hair and Law, "English in Western Africa."

${ }^{4}$ Armitage and Braddick, eds, British Atlantic World; Mancke and Shammas, eds, British Atlantic world; Burnard, "British Atlantic"; Chaplin, "British Atlantic"; Bowen, Mancke, and Reid, eds, Britain's Oceanic Empire. For recent overviews of the vast literature on the Atlantic slave trade, see Morgan, Slavery and the British Empire; Eltis and Richardson, "New Assessment"; Benjamin, Atlantic World, chs 6-7; Richardson, "Cultures of Exchange"; Eltis, "Africa, Slavery"; Burnard, "Atlantic Slave Trade"; Walvin, Crossings.

${ }^{5}$ Burnard, "British Atlantic," 121-2. An important exception is Morgan and Hawkins, eds, Black Experience, but most of its chapters focus on the nineteenth and twentieth centuries. ${ }^{6}$ Curtin, Cross-Cultural Trade, 57-9; Thornton, Africa and Africans; Law and Man, "West Africa"; Northrup, Africa's Discovery; Northrup, "West Africans"; Inikori, "Africa and the
} 
In this article I seek to contribute towards this incorporation by examining two English voyages to West Africa during the 1640s, the period in which, it has been argued, the British (or at least the English) Atlantic took identifiable shape. ${ }^{7}$ In studying these voyages in close detail, I am influenced by recent essays in "global microhistory." ${ }^{8}$ If such an approach is not necessarily microhistory as it was understood by its Italian founders, it nevertheless offers a new angle on the vast scale of global history, especially Miles Ogborn's concept of "trace studies," which "emphasize moments of movement and negotiation, and their residual effects." $"$ The two cases considered here represent such moments of negotiation and conflict involving English seafarers and West African communities, which resulted in lawsuits and are therefore described in the papers of the High Court of Admiralty in London. This court was the major institution in Britain for punishing seaborne crimes such as piracy, and for resolving disputes between merchants, shipowners, and seafarers, and its reliance on written testimony has left a copious collection of evidence concerning maritime and commercial activity. Scholars have previously noticed both of the lawsuits examined here, and indeed the admiralty court's records have long been used to provide incidental evidence on British trade in West Africa and to examine specific voyages. ${ }^{10}$ So far, however, no one has reconstructed these two

Globalization Process"; Chambers, "Black Atlantic"; Yerxa, Recent Themes; Green, "Creole Identity"; Morgan, "Africa and the Atlantic"; Richardson, "Cultures of Exchange"; Law, "Africa in the Atlantic"; Northrup, "Africans, Early European Contacts"; Havik and Green, "Brokerage"; Nafafé, "African Voice."

${ }^{7}$ Pestana, English Atlantic; see also Bliss, Revolution and Empire; Brenner, Merchants and Revolution; Linebaugh and Rediker, Many-Headed Hydra; Roper, "The Ties That Bound." ${ }^{8}$ Ogborn, Global Lives; Andrade, "A Chinese Farmer"; Ghobriel, "The Secret Life"; see also Ginzburg, "Latitude, Slaves, and the Bible"; Putnam, "To Study the Fragments/Whole;" Green, "Créole Identity."

${ }^{9}$ Ogborn, "Editorial: Atlantic Geographies", 382; see also Heywood, "The English in the Mediterranean". On different meanings of "microhistory," see Trivellato, "Is There a Future"; I am grateful to Maria Fusaro and Colin Heywood for discussions about microhistory.

${ }^{10}$ Davies, Royal African Company; Blake, "English Guinea Company”; Blake, "English Trade"; Fyfe, Sierra Leone Inheritance, 59-62; Rodney, Upper Guinea Coast, 127, 163; Jones, "Kquoja Kingdom," 38; Thornton, Africa and Africans, 39; Appleby, "A Guinea Venture"; Appleby, "“Business of Much Difficulty'," 7; Gragg, "'To Procure Negroes," 76; Law, "Scottish Guinea Company." 
cases in their entirety across the various series of court records, or considered their wider implications.

Like the voyage narratives and descriptive compilations which have provided some of the most important sources for scholarship on Atlantic Africa during this period, the admiralty court documents conform to a peculiar set of conventions and were produced for a specific purpose and audience, and even where describing interactions with African individuals they present an essentially European viewpoint. ${ }^{11}$ Unlike these documents, the admiralty papers rarely represent a single narrative or voice, as court procedure required litigants to submit allegations, to which witnesses and defendants responded in their depositions. Yet that is part of their appeal, for even if seafarers' statements were mediated by the lawyers who represented and advised them and the scribes who actually wrote their words down, these sources offer multiple perspectives from individuals of varying social status. ${ }^{12}$ I will briefly set out the background of the first century of British trade to West Africa, and then turn to the two lawsuits themselves to consider what they reveal about British commercial activity in this region and its place in the wider Atlantic world.

\section{British trade to West Africa, 1550-1672}

In the fifteenth century, European voyages to Sub-Saharan Africa were dominated by the Portuguese. Thereafter their monopoly faltered because, on the one hand, "Portugal's Africa trade was heavily embedded in a European financial and mercantile system that rose above state affiliation," and on the other hand African traders and Luso-African communities known

\footnotetext{
${ }^{11}$ For overviews see Jones, Raw, Medium, Well Done; Jones and Heintze, "Introduction," and the other essays collected in that volume; Hair, "Early Sources"; Chouin, "Vu, Dit ou Déduit?"

12 Blakemore, "Legal world"; Blakemore, "Orality and Mutiny."
} 
as lançados traded quite happily with Portugal's competitors. ${ }^{13}$ Regular English voyages to West Africa began in the 1550s, received partial support from the crown, and included attempts to trade in slaves or seize captives by violence. ${ }^{14}$ Although the Portuguese do seem to have warned the English off the Gold Coast after 1571, Elizabeth I issued letters patent in 1588 to a group of merchants for trade to Senegambia, which were renewed ten years later. In 1592 another license was issued for trade to Sierra Leone, and by the turn of the century commerce with these areas had become relatively continuous. ${ }^{15}$ A voyage to Sierra Leone in 1607 may even have involved a shipboard performance of Hamlet. ${ }^{16}$

For the next seven decades, British commercial activity to this region was defined by a series of monopoly companies which struggled, just as the Portuguese had, to establish themselves against both European competitors and British interlopers. ${ }^{17}$ The "Company of Adventurers of London trading to Gynney and Bynney," often known as the Guinea Company, was incorporated in 1618 with a monopoly on trade to the whole of West Africa, though the practical focus remained upon Senegambia and Sierra Leone, where there were probably resident English traders from 1611 onwards. The company ran into financial and political difficulties, their charter was suspended in 1625 , and many of the original members ceased to

${ }^{13}$ Quoting Ebert, "European Competition and Cooperation," 72; see Blake, Europeans; Rodney, "Portuguese Attempts"; Rodney, Upper Guinea Coast, ch. 6; Blake, West Africa; Boulègue, Luso-Africains; Horta, "Luso-African Identity"; Brooks, Eurafricans; Benjamin, Atlantic World, 109-24, 187-97; Disney, Portugal and the Portuguese Empire, vol. 2, chs 16-17; Mark and Horta, Forgotten Diaspora, 38-41; Newitt, Portuguese; Nafafé, "African Voice"; Silva, Dutch and Portuguese, 143-5, 155-9, 192-8, 303-5.

${ }^{14}$ On this first stage see Hair, "Protestants as Pirates"; Andrews, Trade, Plunder and Settlement, ch. 5; Alsop, "Sea Surgeons"; Hair and Alsop, English Seamen and Traders; Alsop, "Career of William Towerson"; Hair, "Experience of the Sixteenth-Century English Voyage"; Hair and Law, "English in Western Africa," 243-9; Perrault, Early English Encounters, ch. 3; Alsop, "Tudor Merchant Seafarers."

15 Jenkinson, "English African Companies," 193-4; Blake, "English Trade," 316-26; Hair and Law, "English in Western Africa," 248, 250.

${ }^{16}$ Hair, "Hamlet in an Afro-Portuguese Setting."

${ }^{17}$ For the first half of the seventeenth century, see Jenkinson, "English African Companies," 194-5; Blake, "English Guinea Company"; Blake, "Farm of the Guinea Company"; Porter, "Crispe Family," 57-66; Hair and Law, "English in Western Africa," 249-55. 
participate during the later 1620s. However, a series of new members reinvigorated the company. These included Humphrey Slany and his protégés Cloberry, John Wood, and Nicholas Crispe, who (both as company members and on their own) invested in the trade in camwood from Sierra Leone and Sherbro, seemingly the most profitable branch of the company's activities. ${ }^{18}$ Crispe, who was also involved in the East India Company, became the majority stakeholder of the Guinea Company in 1628, after which he seems to have quarrelled with Slany and Cloberry for pursuing interloping voyages outside of the company. ${ }^{19}$

The company's unpaid creditors began legal proceedings against them in 1631, but it was also around this time that they took on the services of the Dutch merchant Arent de Groot, who, having previously traded on the Gold Coast, promised "to gaine them the whole trade at Cormantyne." ${ }^{20}$ Crispe and De Groot together drove a reorganisation of the company: Charles I withdrew the former patents and issued a new charter for a thirty-one year monopoly over "Red-Wood, Elephants-Teeth, Hides, Waxe, Gummes, or Graines of those Countreys... or any other of the Commodities of those Countreys." ${ }^{21}$ Their first attempt at a settlement on the Gold Coast faltered, but De Groot then secured permission — despite Dutch resistance-from the Fante ruler to build factories, first at Kormantin and later at Anomabu. Initially these new endeavours were less profitable than the trade in camwood, which apparently employed a thousand tons of shipping by the time of Slany's death in 1637, but during the later 1630s gold

\footnotetext{
${ }^{18}$ Camwood (baphia nitida), also called African sandalwood, is a hardwood used to produce a red dye, the name probably deriving from the Temne word $k^{\prime}$ am: Davies, Royal African Company, 220; Rodney, Upper Guinea Coast, 158-60, 162-3; Barbot, Barbot, 236-7; Mokyr, Oxford Encyclopedia of Economic History, 117, 325-6; Eltis, “Africa, Slavery,” 273. ${ }^{19}$ Porter, "Crispe family"; Ashton, "Crisp, Sir Nicholas."

${ }^{20}$ TNA HCA 13/118, no folio numbers, answer of Arent de Groote, 28 June 1642; Blake, "Farm of the Guinea Company," 89 n. 1. For overviews of European activity on the Gold Coast, see Daaku, Trade and Politics; Kea, Settlements; Feinberg, "Africans and Europeans." ${ }^{21}$ Charles I, A Proclamation Concerning the Trade of Ginney.
} 
shipments reached England more regularly, and the company began to fortify Kormantin in 1638 , and claimed trade rights in other places. $^{22}$

Up to the 1630s this commerce was largely an English affair, though Scottish sailors and ships worked for the English and Dutch companies. In 1634, however, Charles I granted a charter to four Scottish courtiers, at least two of whom were also involved in colonising Nova Scotia. The company was cover for an international operation, as they went into business with German, Dutch and Swedish merchants and in 1636-7 set out two ships, one of them commanded by George Ireland, a central figure in the second lawsuit discussed below. The voyage was not a success. They struggled to trade at Kormantin and twice put into São Tomé, once deliberately, the second time after the ship sprang a leak. On this later occasion the mariners were seized and imprisoned, and most of them were executed, probably in a misplaced retaliation to the recent seizure of the Portuguese fort São Jorge da Mina by a large Dutch expedition. The Scottish company seemingly made no further voyages, although Scottish merchants continued to work for other trading companies and a new Scottish company was formed in $1695 .^{23}$

Civil war in Britain and Ireland during the 1640s brought substantial changes for the English company. ${ }^{24}$ Crispe was initially elected to parliament, but was expelled and later joined the king, for whom he organised privateers against the parliamentarians. In 1643 parliament proclaimed him a "delinquent," later seizing his stake in the company, with John Wood managing it. ${ }^{25}$ In 1649-51, however, the company was challenged by Samuel Vassall, another leading parliamentarian merchant. Although the company's monopoly was maintained—with

\footnotetext{
${ }^{22}$ Lawrence, Trade forts, 245-9.

${ }^{23}$ Law, "Scottish Guinea Company."

${ }^{24}$ For the 1640s-60s see Porter, "Crispe family," 65-74; Hair and Law, "English in Western Africa," 249-56.

${ }^{25}$ Ashton, "Crisp, Sir Nicholas"; Blakemore, "London and Thames Maritime Community," 169-70, 248.
} 
Vassall now a member - it was geographically restricted between Sherbro and Kormantin, and suffered from Dutch and Swedish competition. ${ }^{26}$ In 1657 the company leased their rights and assets to the East India Company, who sought African commodities for Indian markets. ${ }^{27}$ It was also during the 1640 s-50s that slave trading became a more substantial part of British Atlantic commerce, although this was mainly conducted outside of the Guinea Company. ${ }^{28}$

With the restoration of the monarchy a group of courtiers set up the new Company of Royal Adventurers into Africa. They reached an accommodation with the East India Company (whose lease technically lasted until 1664), and in 1663 the Royal Adventurers received a new charter, with slave trading now explicitly amongst its purposes. Their interests were devastated by the Second Anglo-Dutch War, but in 1672 yet another new company was formed, the Royal African Company, which lasted until 1750. ${ }^{29}$ The first century of British trade to West Africa thus reveals a number of key characteristics of this commerce. Merchants and seafarers of different nationalities cooperated across trading companies, but also engaged in fierce and frequently violent competition both between states and amongst the traders of any one nation. Monopoly companies regularly failed to control trade, and this was strongly influenced by the political situation in Europe.$^{30}$ It was also a consequence of the political situation in Africa, and a similar degree of instability is apparent in relations between African and European associates, as we shall see in the two case studies.

\section{"To take Negroes": Portudal, 1645}

\footnotetext{
${ }^{26}$ Appleby, "Vassall, Samuel."

${ }^{27}$ Makepeace, "English Traders."

${ }^{28}$ Appleby, "A Guinea Venture”; Appleby, “"Business of Much Difficulty”; Gragg, "To Procure Negroes"”; Games, "The Sanctuarye of Our Rebell Negroes."”

29 Jenkinson, "English African companies," 198-203; Davies, Royal African Company; Porter, "Crispe family," 73-4; Law, Local Correspondence; Hair and Law, "English in Western Africa," 256-62; Pettigrew, "Regulatory Inertia."

${ }^{30}$ See also Ebert, "European Competition and Cooperation"; Antunes and Silva, "CrossCultural Entrepreneurship"; Silva, Dutch and Portuguese, 306-17.
} 
The first case was not a standard admiralty lawsuit. On 20 April 1646 a petition was submitted to parliament's committee for foreign plantations by “divers Marchants trading to Ginney, and to the English plantations in America," complaining about certain acts by Robert Shapton, Miles Cawson, and James Smith. This committee referred the petition to the admiralty judge "to take Examinacion of all such witnesses, as shall be produced." ${ }^{31}$ Four days later Rowland Wilson and John Wood, merchants trading to "Guiney [and] Binney," appointed a proctor to represent them in court, and soon afterwards named the witnesses they wished to present. ${ }^{32}$ Wood we have already met; Wilson was also involved in both the East India and Guinea Companies and fought for parliament during the civil wars. ${ }^{33}$ After 24 April the case does not appear again in the court's acts books, but both parties submitted written allegations, and interrogatories directed at their opponents' witnesses. $^{34}$ Six witnesses were examined throughout May 1646, but what happened afterwards remains a mystery. ${ }^{35}$ The committee had ordered that "upon returne [of the depositions], further order shall be taken"; unfortunately their papers do not survive. ${ }^{36}$

The three defendants were shipmasters from London with experience in Atlantic shipping, and two of them were also (like their accusers) connected to the parliamentarian cause. In July 1646, just after the case discussed here, Robert Shapton claimed he had been a shipmaster for twenty years and often traded to the Caribbean, and he and Joseph Jordaine, who later fought for parliament, seized a Spanish vessel near Hispaniola in $1641 .^{37}$ Three years

\footnotetext{
31 TNA HCA 30/849/636.

32 TNA HCA 3/42, 198r, 199v.

${ }^{33}$ Lindley, "Wilson, Rowland."

34 TNA HCA 24/108/7-8; HCA 23/14/415; the defendants' witnesses were also examined upon interrogatories by Wilson and Wood, which do not survive.

${ }^{35}$ TNA HCA 13/60, depositions of William Eaton, William Wager, and Andrew Bengellye, 4 May 1646, 546-9r, John Cutler, 5 May 1646, 575r-6r, and William Foulgiar and John Hacker, 26 May $1646,531 \mathrm{v}-2 \mathrm{v}$.

${ }^{36}$ TNA HCA 30/849/636.

37 TNA HCA 13/60, deposition of Robert Shapton, 7 July 1646, 637v; HCA 23/14/21, 79, 183; HCA 13/57, no folio numbers, depositions of Thomas Jones, 14 December 1641, and
} 
later, during the civil wars, Miles Cawson reported to parliament on the actions of the royalist forces that he had encountered during his Atlantic voyages as master of the George. ${ }^{38}$

James Smith had not had so successful a career. He was accused of refusing to take the Rainebow back to England "as longe as shee would swyme because he owed soe much money"; instead he moved his family to Barbados and built a house in New England. ${ }^{39}$ Apparently he was unable to sell the ship legally, but he found new business partners in Boston, one of whom, Thomas Keyser, joined Smith as master's mate and agent for the other merchants. John Winthrop, governor of New England, wrote that when a Portuguese ship arrived in 1644 and "the seamen stole divers goods," Smith was ordered "to require the Portugal to give satisfaction." Smith sent Keyser, who "did not reason the case" with the Portuguese commander, but instead "presently boarded him... and his men fell to rifling the ship, as if she had been a prize." ${ }^{40}$ Keyser was later ordered by Boston's magistrates to repay the Portuguese sailors, though by then the Rainebow had already set sail on the voyage studied here. ${ }^{41}$ Like Shapton and Cawson, Keyser probably had some previous experience of maritime warfare, and was evidently prepared to play fast and loose with prize law. ${ }^{42}$

Wilson and Wood claimed in their petition that at Portudal, on the Petite Côte just south of Cape Verde, the defendants "by force \& violence tooke the Natiue people being Blackes from the shoare, putt them aboard their ships, and carried them for the Barbados, where they

Edward Garrett, 23 December 1641; HCA 13/58, depositions of William Brathwhate and John Corbett, 4 May 1642, 25r-6v, 30r-2v; HCA 13/118, no folio numbers, answer of Robert Shapton, 3 February 1642[/3].

${ }^{38}$ Royal Commission on Historical Manuscripts, Manuscripts of His Grace the Duke of Portland, vol. 1, 168.

${ }^{39}$ TNA HCA 23/14/319, 343; HCA 13/60, deposition of John Denton, 26 June 1645, 90r-v, and Thomas Grave and Richard Bartholmew, 11 April 1646, 534r-v.

${ }^{40}$ Hosmer, Winthrop's Journal, vol. 2, 251-2.

${ }^{41}$ Shurtleff, Massachusetts Bay, vol. 2, 79. Massachusetts Archive 60:144 is an agreement between Smith, Keyser, Shapton and Cawson for their voyage, cited in Moody, Saltonstall papers, 138-9.

${ }^{42}$ Benton, "New Legal History"; Rodger, "Law and Language"; Blakemore, "Politics of piracy." 
sould them to Planters." 43 Their main concern was that this "tendeth much to the destruction of that Trade and Comerce, which your petitioners haue in those parts, $\&$ to the dishonor of our nation." ${ }^{44}$ In their written allegation, the petitioners stated that Cawson and Shapton informed the companies of their ships (the Blossome and the Seaflower) that their plan was to "take Negroes," and that they were employed by the earl of Warwick, admiral of the parliamentarian fleet and an investor in both privateering and colonisation; Shapton's earlier privateering had also been "by a lawfull Commission" granted by Warwick. ${ }^{45}$ According to their accusers, Shapton and Cawson sent out boats "armed in warlike manner," but finding that it was too dangerous to land at Portudal, presumably because the shoreline was difficult or the town was well defended, they turned to "pollicye." ${ }^{46}$ Cawson and Shapton invited the "Alcade," the alkati or governor, aboard with various companions. ${ }^{47}$ Although they were initially "entertained," these guests were then imprisoned aboard the ships until they "redeemed" themselves by exchange with other "Negroes," who were "carried away" to Barbados and sold. ${ }^{48}$

Some of the captives, Wilson and Wood claimed, were "interpreters" and "linguists" without whom it was difficult for Europeans to conduct trade. As knowledge of European

43 TNA HCA 30/849/636.

${ }^{44}$ Ibid.

45 TNA HCA 24/108/7; Kelsey, "Rich, Robert"; TNA HCA 13/118, no folio numbers, answer of Robert Shapton, 3 February 1642[/3].

${ }^{46}$ All quotations in this paragraph are from TNA HCA 24/108/7. Contemporary descriptions noted that Portudal was a difficult anchorage: Dapper, Naukeurige Beschrijvinge, 339; Barbot, Description, 23; Newitt, Portuguese, 83. Some writers claimed that there were no fortifications or palaces in this region (e.g. Dapper, Naukeurige Beschrijvinge, 338), but others praised the magnificent residences of the rulers (e.g. Saint-Lô, Relation, 154; Le Maire, Voyages, 140).

47 The Wolof terms alkati and alkaire were probably drawn from Arabic al qâdi, "judge," or al qâid, "chief," either through Portuguese, widely spoken in coastal Senegal, or due to the Muslim presence in this region: see Hair, "Ethnolinguistic Inventory," 34; Levtzion, "NorthWest Africa," 202; Curtin, Economic Change, 96; Davidson, West Africa, 96.

${ }^{48}$ A separate case concerned Cawson's conduct at Barbados: TNA HCA 24/108/101-2; HCA 23/15/109; HCA 13/61, depositions of William Foulger, Christopher Cole, Richard Denby, and Robert Waugh, 20 January 1647[/8], Thomas Wilbraham, Philip Jourdan, Thomas Webber, and Edward Skamen, 21 January 1647[/8], 6v-14r; HCA 13/120, no folio numbers, answer of Miles Cawson, 17 January 1647[/8]; cf. HCA 3/42, 383r, 388v. 
languages was widespread in Portudal and along the Petite Côte, these "interpreters" probably acted as negotiators rather than in a purely linguistic capacity. ${ }^{49}$ They were most likely members of Portudal's lançado community, many of whom were openly-practicing Sephardic Jews, who operated as middlemen between European merchants and trading networks further inland. ${ }^{50}$ If the "interpreters" were indeed lançados, then the description of them as "Negroes" or "Blackes" by both sides in the court case might reflect emergent European assumptions which privileged physical attributes in a way that earlier commentators and lançados themselves did not: the English merchants and sailors either failed to recognise, or retrospectively obscured, cultural definitions which Luso-Africans articulated as part of multifaceted identities. ${ }^{51}$

Four of the witnesses broadly agreed with the accusations. They stated that Cawson and Shapton had indeed made their intentions known to their crews before arriving at Cape Verde, and confirmed Warwick's involvement; his share was "the $5^{\text {th }}$ Negroe of all that they should take." 52 The mariners, "dislikinge the said designe," were offered a share in the profits above their wages as an encouragement. ${ }^{53}$ John Hacker in particular testified that he had opposed Cawson, claiming that "his designe was not lawfull," but Cawson "told him hee was a Coward"

\footnotetext{
${ }^{49}$ Marees, Beschryvinghe, 7; Broecke, Journal, 35-6; Wassenaer, Historisch Verhael, vol. 5, 92r; D’Avity, Description, 388; Villault, Relation, 53; Barbot, Barbot, 49; cf. Thornton, Africa and Africans, 215; Northrup, "West Africans," 50. A creole language also developed on the Petite Côte; Boulègue, Luso-Africains, 51-2; Mark, "Portuguese' Identity," 175-6. ${ }^{50}$ Blake, "English Trade," 320; Thornton, Africa and Africans, 60-1, 69; Rodney, Upper Guinea Coast, 74-94, ch. 9; Boulègue, Luso-Africains, especially 28-31, 43-6; Mark, "'Portuguese' Identity"; Brooks, Eurafricans; Mark and Horta, "Sephardic Communities"; Green, "Further Considerations"; Disney, Portugal and the Portuguese Empire, vol. 2, 51; Mark and Horta, Forgotten Diaspora, ch. 1; Havik and Green, "Brokerage"; Nafafé, "African Voice," 79-86; Newson, "Africans".

${ }^{51}$ Mark, "'Portuguese' Identity," 184-6; Horta, "Luso-African Identity,” 103, 113-14;

Kř́žová, "Frontiers of Race"; Mark and Horta, Forgotten Diaspora, 54-8, 64-5, 78-81; See also Hair, "Attitudes"; Hatfield, "Very Wary People"”; Green, "Creole Identity."

52 TNA HCA 13/60, 547r, 548v-9r, 591r, 592r-v.

${ }^{53}$ Ibid., 547r, 548v-9r.
} 
and threatened him with the loss of all his wages. ${ }^{54}$ The witnesses agreed that Shapton, Cawson and Smith had planned to attack the town, but instead invited the alkati and some companions aboard, and imprisoned them, forcing them to provide others in exchange who were then sold at the Cape Verde Islands and Barbados. ${ }^{55}$ Most of them also acknowledged that some of the captives were "Interpreters." 56

Cawson and Shapton's story, though similar in outline, was very different in emphasis. According to their allegation and interrogatories, Cawson had previously travelled to Portudal and "Brisall" in 1642-3, and received permission to put his goods ashore and trade. Even though he paid "all Customes and other dues," Cawson's warehouse was attacked, his men were beaten, and his goods were taken; in addition the Tryall, a small vessel with more of his merchandize aboard, was seized and the men attending to it were killed. ${ }^{57}$ The defendants produced two witnesses who had served on that previous voyage, who confirmed these claims, and one sailor from the later voyage remembered hearing Cawson say that when he originally complained to the alkati about the attack he was "laughed at and slighted." 58

European competition might have been a factor in these events. The Tryall, seized in the Gambia, was reportedly sold to some French merchants. ${ }^{59}$ Despite the petitioners' claims that the English were "in better esteeme with these Natiues, then either the French or Dutch," a reputation they saw endangered by Cawson's violence, French and Dutch merchants actually dominated seaborne trade in this region, although the Portuguese were still participants. ${ }^{60}$ The lançados also jealously guarded their privileged position, and had reportedly killed English and

\footnotetext{
${ }^{54}$ Ibid., 532r; cf. Appleby, “'Business of Much Difficulty'," 5.

55 TNA HCA 13/60, 547r-9r, 591r, 592r-v.

${ }^{56}$ Ibid., $547 \mathrm{v}, 548 \mathrm{v}-9 \mathrm{r}$.

57 TNA HCA 24/108/8; HCA 23/14/415.

58 TNA HCA $13 / 60,573 \mathrm{v}-4 \mathrm{r}, 575 \mathrm{r}-6 \mathrm{v}, 591 \mathrm{v}$.

${ }^{59}$ TNA HCA $13 / 60,548$ r.

${ }^{60}$ Quoting TNA HCA 30/849/636; see Boogart, “Trade," 373; Rodney, "Portuguese Attempts," 312; Boulègue, Royaumes Wolof, 181-9.
} 
French seafarers before, so it is possible that Cawson had somehow threatened their trading interests. ${ }^{61}$ Yet English traders had called at Portudal before and continued to do so into the eighteenth century, so these difficulties were probably more individual to Cawson. ${ }^{62}$

Olfert Dapper, who compiled one of the most well-known contemporary descriptions of Africa, claimed that the inhabitants of the coast near Portudal were "much more malignant" than elsewhere. ${ }^{63}$ Dapper may have taken this description from Alexis de Saint-Lô, a French Capuchin who visited the Petite Côte in 1635, who wrote that the inhabitants of Portudal were not good trading partners, mainly because the ruler of Baol (of which Portudal was the chief port), the teeñ, was "greatly malicious" and did not punish the "insolence" of his people as severely as neighbouring rulers did. ${ }^{64}$ Later in the century Francisco de Lemos Coelho, a trader familiar with the region, wrote that the teeñ, whom he named "Denchafur," "was very evil and robbed many whites." 65 These statements are clearly judgemental and probably exaggeratedDaou Demba, the contemporary damel of neighbouring Cayor, was also traditionally known as an "immoderate and cruel prince"-but they suggest the possibility that Cawson fell afoul of the local authorities. ${ }^{66}$ It was generally observed that the teeñ claimed the right to seize the possessions of all Europeans who died within his realm, while Coelho said that any "whiteman" who wished to leave Portudal had to so "with great caution and care," or "the blacks...would immediately rob him. ${ }^{\prime 67}$ This may have happened as a punishment when Europeans breached

\footnotetext{
${ }^{61}$ Hakluyt, Principal Nauigations, vol. 2 part 2, 189-91; Rodney, Upper Guinea Coast, 209; Brooks, Eurafricans, 59, 84, 130.

${ }^{62}$ Blake, "English Trade," 327-8; Traoré, "State Control," 70.

${ }^{63}$ Dapper, Naukeurige Beschrijvinge, 347.

${ }^{64}$ Saint-Lô, Relation, 102-3. For analysis of the relationships between contemporary compilations, see Hair, "Editing Barbot"; Hair, "Barbot, Dapper, Davity"; Thilmas, "Sénégal"; Jones, "Decompiling Dapper"; on the early Capuchin missions to West Africa, see Lintingre, "La Mission."

${ }^{65}$ Coelho, Description, 9; cf. Thilmans, "Sénégal," 517-17; Wassenaer, Historisch Verhael, vol. 5,92 r.

${ }^{66}$ Suret-Canale, "Western Atlantic Coast," 404.

${ }^{67}$ Dapper, Naukeurige Beschryvinghe, 350; Barbot, Barbot, 128-9; Boulègue, Luso-

Africains, 62-3; Coelho, Description, 9.
} 
a local rule or custom, so it is possible that Cawson committed some such transgression, and unsurprisingly failed to mention this in court. ${ }^{68}$

Alternatively, perhaps he failed to grasp the political situation in the region. Indeed, the impression from the sailors' depositions is that they had only a sketchy understanding, although this might reflect the documents' concise legal style as much as the sailors' ignorance. Besides the alkati of Portudal, who was also described as a "vice king," the deponents mentioned other "kings or Cheife officers" and other towns-"Trefisco" (Rufisque), "Brisall," "Joallie" (Joal) - all apparently under the "subiection of the kinge of Porto Dallye." ${ }^{69}$ In fact, though all previously part of the Jolof empire, the coast was divided between separate polities by the midseventeenth century: Rufisque lay in Cayor, and Joal to the south was the main port of Sine. ${ }^{70}$ In the later sixteenth century the damel Amari Ngoone had also ruled Baol as teeñ, but this dual monarchy did not outlast him and the two realms remained separate. ${ }^{71}$ Coelho wrote of "continual war between this one and that one," while Saint-Lô recorded an incident when the residents of Joal repelled an attack from Portudal, and described a rebellion within Baol provoked by taxes to pay for the wars that the teeñ made upon his neighbours "without cease, and without reason." 72

Saint-Lô also reported a complaint by the teeñ about the fairly common practice of larger European ships anchoring in deep water near the island of Gorée or calling at Rufisque

\footnotetext{
${ }^{68}$ Rodney, Upper Guinea Coast, 86-7, 108.

${ }^{69}$ TNA HCA 24/108/8; HCA 13/60, 573v-4r, 575r-v; cf. Farrar, "African Kings."

${ }^{70}$ For contemporary descriptions, see Almada, Brief Treatise, 18-22, 27-9; Hakluyt,

Principal Nauigations, vol. 2, part 2, 189-92; Dapper, Naukeurige Beschrijvinge, 337;

Villault, Relation, 52-3; Coelho, Description, 1-11; Barbot, Barbot, 37-8; Le Maire, Voyages, 94-6; the best summary is Boulègue, Royaumes Wolof, 163-77.

${ }^{71}$ Levtzion, "North-West Africa," 202; Barry, Royaume du Waalo, 72-84; Suret-Canale, "Western Atlantic Coast"; Barry, Sénégambie, 35, 43-4; Boulègue, Royaumes Wolof, 171-7.

${ }^{72}$ Coelho, Description, 2; $\quad$ Saint-Lô, Relation, 117, 149; cf. Dapper, Naukeurige

Beschrijvinge, 353 (also possibly derived from Saint-Lô).
} 
but only sending smaller vessels to trade at other ports. ${ }^{73}$ The depositions are not precise, but it is possible that in 1642-3 Cawson attempted to trade at "Brisall," or somewhere other than Portudal, and may also have stopped elsewhere before coming to Portudal in $1645 .{ }^{74}$ Perhaps Cawson angered the teeñ by trading with his neighbours, or if not the teeñ then the alkati of Portudal. Every town along the coast was governed by an alkati who, as European travellers and writers were quick to complain, demanded their own fees for allowing ships to trade. ${ }^{75}$ Though Cawson protested in court that he had paid "all Customes and other dues," it is possible that he had not done so everywhere he called, which might also explain why the Tryall was seized in the Gambia, which (as the defendants' witness admitted) was sixty leagues away from Portudal and "not all under one Kinges Command."76

Whatever the reason behind the alleged attack, it highlights the importance of maintaining a good relationship with local authorities, but Cawson does not seem to have learned this lesson. ${ }^{77}$ The defendants maintained that in their later voyage they sought "to demand satisfaction and restitution," and to attempt to trade once again. Their allegation stated that Cawson and some others had first gone ashore to seek redress, but were imprisoned by the alkati. ${ }^{78}$ Shapton and some of their men went ashore to "releiue" them, and managed to do this peacefully despite, they claimed, being attacked by some 4-5,000 men, who "shot Arrowes,"

\footnotetext{
${ }^{73}$ Saint-Lô, Relation, 137-8; Hakluyt, Principall Nauigations, vol. 2, part 2, 189; Broecke, Journal, 26-7, 31-4; Ruiter, Toortse der Zee-vaert, 50-1; Brooks, Eurafricans, 61.

${ }^{74}$ William Foulger's deposition, in which he stated that they came to Portudal but then "removed from thence and came and anchored at Porto Dalle," might suggest a more complex itinerary in 1645: TNA HCA 13/60, 591r.

${ }^{75}$ Hakluyt, Principall Nauigations, vol. 2, part 2, 190; Moraes, Découverte, vol. 1, 63, 168-9; Marees, Beschryvinghe, 10; Wassenaer, Historisch Verhael, vol. 5, 91v; D’Avity, Description, 389; Saint-Lô, Relation, 31-2, 47-55, 109; Jannequin, Voyage, 57-8, 60-6, 91; Dapper, Naukeurige Beschrijvinge, 354; Coelho, Description, 6; Barbot, Barbot, 47; Le Maire, Voyages, 181; Barbot, Description, 22-3, 44, 58; cf. Brooks, Eurafricans, 83; Boulègue, Royaumes Wolof, 238-46.

${ }^{76}$ TNA HCA $13 / 60,574 \mathrm{v}, 575 \mathrm{v}$.

${ }^{77}$ On this point see Curtin, Economic Change, 121-7, 286-95; Elbl, "Cross-Cultural Trade," 168, 178; Thornton, Africa and Africans, 55-6; Perreault, Early English Encounters, 150-1. 78 TNA HCA 24/108/8.
} 
so that Shapton would have "bine therewith slaine in case hee had not most miraculouslye turned his head on one side." ${ }^{, 79}$ They further stated that they only detained prisoners aboard ship in the hope of "satisfaction" and in response to this violence. Another English ship had done so in 1643, they argued, and then returned the prisoners when their demands were met; Cawson and Shapton said that they would have done the same, "if they could have received satisfaction for their dammage." 80

The testimony of the witnesses and the arrangement with Warwick suggests that Cawson and Shapton intended all along to acquire slaves, but such trade was well-established in Senegambia. According to the Transatlantic Slave Trade Database, 120 voyages embarked 29,540 slaves from this region in the years $1600-1650 .{ }^{81} \mathrm{~A}$ violent approach was therefore not inevitable, as Cawson and Shapton argued, but it does seem to have been contemplated from the beginning. William Foulger, a mariner of the Seaflower, recalled that Cawson said "if the inhabitants there would not trade with him... then hee would by fayre meanes or other take and seize uppon them," though Foulger added that Cawson was initially reluctant to go through with the "pollicye" of extortion until Shapton imprisoned the alkati and some others aboard the Blossome. ${ }^{82}$ John Denton, in one of the lawsuits concerning James Smith's debts, deposed that he left the Rainebow during a previous voyage because Smith "would then haue gon upon the

\footnotetext{
79 TNA HCA 23/15/415. On warfare in this region see Broecke, Journal, 36; D'Avity, Description, 389; Jannequin, Voyage, 86-92; Dapper, Naukeurige Beschrijvinge, 352; Le Maire, Voyages, 183-5; Thornton, Warfare in Africa, ch. 2; Boulègue, Royaumes Wolof, 247-50.

${ }^{80}$ TNA HCA 24/108/8. On hostages in West African commerce, see Lovejoy and Richardson, "Business of slaving," 75-9.

${ }^{81}$ Trans-Atlantic Slave Trade Database, for the region "Senegambia and offshore Atlantic," excluding the Cape Verde Islands and Madeira. The figures given for Senegambia in Northrup, "Africans, early European contacts" and Eltis and Richardson, "New Assessment" include the islands. For criticisms of these figures, see Lovejoy "Upper Guinea Coast," especially 16-19; Newson, "Africans," 2.

${ }^{82}$ TNA HCA 13/60, 591r-v.
} 
Coast of Guiney there to haue stollen Negroes," so while Smith is hardly mentioned in the later case, these actions may have been proposed by him. ${ }^{83}$

One possible explanation, then, is that a shore party who intended to purchase slaves and seek "satisfaction" instead provoked an aggressive response which quickly escalated. None of the witnesses explicitly mentioned Cawson's alleged seizure by the alkati, but some said that when they went ashore a large crowd gathered and, seeing that the English were heavily armed and fearing that they meant to seize captives, shot at them. ${ }^{84}$ This was not a unanimous action: one witness reported that some of the "better sort" tried to stop it, and another said that some in the crowd recognised Cawson (which, this witness thought, was the only reason they did not kill the landing party). ${ }^{85}$ The impression which emerges is of a fine and tense balance between commerce and conflict, as the situation subsequently calmed enough for the alkati and some companions to go aboard the ships. ${ }^{86}$

There is little sign that this lawsuit provoked any wider debate in England, although it would not be surprising if Warwick, a member of the committee for foreign plantations, protected his associates; he had done so before ${ }^{87}$ However, the participation of the Rainebow resulted in controversy in New England. When the ship reached Barbados, Keyser and Smith quarrelled, because Keyser was suspicious that Smith might sell the ship's cargo and keep the money for himself. After an altercation-Smith was later ordered to pay $£ 10$ to Keyser for

\footnotetext{
${ }^{83}$ Ibid., 90r.

${ }^{84}$ Ibid., 547v-8r, 549r, 591v-2v.

${ }^{85}$ Ibid., $547 \mathrm{v}-8 \mathrm{r}$. The local elite were apparently distinguishable by their attire: Marees, Beschryvinghe, 7-8; D’Avity, Description, 387; Jannequin, Voyage, 96; Dapper, Naukeurige Beschrijvinge, 348; Villault, Relation, 51; Le Maire, Voyages, 132.

${ }^{86}$ The alkati at Rufisque also visited ships: Hakluyt, Principal Nauigations, vol. 2 part 2, 189; Jannequin, Voyage, 57-8; Villault, Relation, 51.

${ }^{87}$ See Blakemore, "London and Thames Maritime Community," 225.
} 
threatening to "pistol him"- Keyser sailed off without Smith, resulting in a lawsuit in Boston, in which a jury initially decided on behalf of Smith, but which later led to an accommodation. ${ }^{88}$

There was also concern in New England over the captives aboard the Rainebow. This was not about the status of slavery itself, as planters in other English colonies had begun to purchase African slaves in previous decades, and some of John Winthrop's correspondents advocated enslaving Native Americans and Africans. ${ }^{89}$ Rather, it was the manner in which they had been captured that was contentious. Richard Saltonstall, an important investor in Massachusetts, considered that Keyser had committed murder and theft (even more damningly "upon the sabbath day"), and Saltonstall petitioned the general court of New England for "justice to be done." 90 The court, "conceiving themselves bound by the first opportunity to bear witnes against the haynos \& crying sinn of man stealing," ordered that "the negro interpreter, with others unlawfully taken, be... sent to his native country of Ginny." 91 They wrote to one of Smith's customers instructing him to release "the neger which he had of Captain Smith," and appointed a committee to examine witnesses concerning Smith's and Keyser's misdeeds, but it seems no further action was taken against them. ${ }^{92}$

This case study conforms to the idea that British interest in West Africa was associated with colonial expansion in the Americas, but it also shows how the boundaries of slavery were contested during the early stages of British involvement in the slave trade. Some seafarers, merchants and politicians_-including some leaders of the British revolution-were eager participants and had few scruples about indiscriminately seizing and selling African people. ${ }^{93}$

\footnotetext{
${ }^{88}$ Hosmer, Winthrop's journal, vol. 2, 252-3; Shurtleff, eds, Massachusetts Bay, vol. 2, 989, 115, 129; vol. 3, 13, 51, 58 .

${ }^{89}$ Gragg, "To Procure Negroes'," 65, 70; Morgan, Slavery and the British Empire, 21; Forbes, Winthrop papers, vol. 5, 38-9.

${ }^{90}$ Moody, Saltonstall papers, 138-9.

${ }^{91}$ Shurtleff, Massachusetts Bay, vol. 2, 168; vol. 3, 84.

${ }^{92}$ Shurtleff, Massachusetts Bay, vol. 2, 136, 176.

${ }^{93}$ Warwick was not the only parliamentarian leader to invest in slave trading: Blakemore, "London and Thames Maritime Community," 243.
} 
Others clearly thought that legal limitations applied, but their extent was uncertain. Winthrop wrote: "For the matter of the negroes, whereof two were brought home in the ship, and near one hundred slain by the confession of the mariners, the magistrates took order to have these two set at liberty, and to be sent home; but for the slaughter committed, they were in great doubt what to do in it, seeing it was in another country, and the Londoners pretended a just revenge." 94

The description of "near one hundred slain" contradicts the defendants' claims of a pacific resolution, and the reference to a "just revenge" presumably relates to the law of reprisal, a system dating back to the medieval period which authorised merchants to seize ships in order to recoup losses suffered when their own ships were seized. This system remained widespread in the early modern period, except that the exact terms of "reprisal" shifted to encompass a range of seafaring aggression. ${ }^{95}$ The Portudal case indicates how commerce and conflict were deeply entwined, especially when clashing conceptions of law and politics were capable of provoking hostility on both sides. ${ }^{96}$

\section{"The sole trade": Sherbro, 1647}

The procedure in this second case is somewhat confused due to the records in the court's acts books. John Wood, the plaintiff, purchased a warrant against 100 tons of "Redwood" brought from "Cerbero" in the Releife, citing Thomas Gallilee and George Ireland as defendants, on 22 June $1648 .{ }^{97}$ The next day Wood appointed a proctor, as did George Hooper, Henry Futter, and Thomas Cust, appearing as co-defendants alongside Ireland. Both proctors alleged that the

\footnotetext{
${ }^{94}$ Hosmer, Winthrop's Journal, vol. 2, 252-3.

${ }^{95}$ Rodger, "Law and Language."

${ }^{96}$ See Gould, "Zones of Law”; Gould, "Lines of Plunder”; Benton, Search for Sovereignty.

97 TNA HCA 38/27, no folio numbers. Gallilee did not appear in this case, but was involved in another lawsuit concerning possession of the Releife: see HCA 24/108/67; HCA 23/15/1, 38; HCA 13/61, depositions of Joseph Alport, 5 June 1648, 80r-v, and John Perrott, 2 May $1649,449 \mathrm{v}$.
} 
cargo belonged to their clients. ${ }^{98}$ There is a first written allegation by Wood dated 24 June, but both this and a second allegation were probably submitted to the court on 29 June. ${ }^{99}$ The defendants had already named one witness on 26 June, and on 29 June both parties produced further witnesses. ${ }^{100}$ They were examined upon the allegations and interrogatories between then and 1 July, and during the same time Futter, Cust and Ireland gave answers to both of Wood's written allegations. ${ }^{101}$ Two days after the last witness was examined the judge ordered the goods to be valued and then released under suitable security, but there was no further action and it seems likely that the litigants settled out of court. ${ }^{102}$ This was not unusual; the majority of admiralty cases were resolved in this way. ${ }^{103}$

As in the first lawsuit, the plaintiff was a Guinea Company merchant and the main defendant was an experienced Atlantic shipmaster. In July 1646 George Ireland stated that he had sailed in the "Guiney trade" for thirty years, as a shipmaster for twenty-three of them. ${ }^{104}$ As noted earlier, he commanded a ship for the Scottish Guinea Company on a voyage to the Gold Coast, and he was also involved in a dispute between De Groot and the English company.

\footnotetext{
98 TNA HCA 3/42, 515v-6r.

${ }^{99}$ Ibid., 527r-8r. There are two entries, one dated Thursday 22 June, but given its position in the acts book and its reference to previous actions in the case, it probably occurred on Thursday 29 June; the second entry is dated 29 June. The allegations are HCA 24/108/232, 247.

${ }^{100}$ Ibid., 522v, 527r. On 26 June, in a different entry (523v), the defendants were declared in contempt for not appearing and a first default was granted.

101 TNA HCA 13/61, depositions of George Franke, 28 June 1648, John Dronne, 29 June 1648, 103r-7v, James Sammis, Richard Howtinge, and Thomas Jemmett, 30 June, 118r-22r, and John Crafford and Michael Woodcocke, 1 July 1648, 108r-9v, 122-3v; HCA 13/121, no folio numbers, answers of Henry Futter, Thomas Cust, and George Ireland, [29-30 June 1648 ] and 30 June 1648. George Franke's deposition, while dated 28 June, may have been taken on 29 June, following the entries in the act books; the first of the defendants' answers is undated but must have been written between 26 and 30 June 1648, most likely on 29-30 June. The defendants' interrogatories are 23/15/182; there are no surviving interrogatories for the plaintiffs, but defendants' witnesses were examined upon them.

102 There are two further entries, on 6 and 11 July 1648, but these only record that the case was continued in its current state: TNA HCA 3/42, 533v, 535v. 103 Steckley, "Instance Cases," 70, 74-5; Steckley, "Litigious Mariners," 325.

104 TNA HCA 13/60, deposition of George Ireland, 20 July 1646, 628r.
} 
Crispe and Wood accused De Groot of insulting and threatening the "Negroes" at Kormantin, driving them to trade with the Dutch, and at the same time of giving priority to his own and Ireland's interests instead of selling the company's goods. ${ }^{105}$

At the heart of the lawsuit was a contest for the right to trade in camwood in Sherbro. ${ }^{106}$ This region of mangrove swamps and winding, interconnecting rivers was apparently ruled by Towa, named in the court documents as the "kinge" of the "River of Cerbero \& of the Rivers \& Streames of Kiddam Marap \& Melin."107 The court documents refer to the town of "Toma," also called "Tomo in the River of Boome" and "Toma's port or place." 108 This is probably Tormabum on the Sewa River, appearing on a nineteenth-century map as "Tomah" on the river "Boom." 109 Jean Barbot, drawing on Dapper, described a "Prince of Bolm" residing at the town Baga, who was subordinate to the Kquoja ruler at Cape Mount to the south. ${ }^{110}$ However, contemporary writers also mentioned the presence of a "king" at Sherbro Island, who may have claimed overlordship over the "Bolm" region at some point. ${ }^{111}$ As in the previous case, in identifying Towa as the "kinge" of this area the witnesses were misunderstanding, or at least misrepresenting, a more complex political system.

105 TNA HCA 23/14/69, 78, 140; HCA 13/61, depositions of William Thompson and Mathew Reeve, 27 May 1642, Edward Archer, 28 May 1642, 105r-11r, Thomas Hewett, 3 June 1642, 124v-7r; HCA 13/118, no folio numbers, answer of Arent de Groot, 28 June 1642. There was also a separate wage case from this voyage: HCA 23/14/56, 76; HCA 13/61, deposition of George Ireland, 9 June 1642, 135v-6v.

106 On Sherbro see Davidson, West Africa, 99-102; Kup, History of Sierra Leone, 24-5, 127; Alie, New History of Sierra Leone, 12, 17-18.

107 TNA HCA 24/108/232; HCA 13/61, 103v, 106r-v, 108r, 118r-v, 119r-v, 120v-1r, 122r-v; HCA 13/121, no folio numbers, answer of Henry Futter, Thomas Cust, and George Ireland, [29-30 June 1648].

108 TNA HCA 13/61, 105v-6r.

${ }^{109}$ Newcomb, Cyclopedia of Missions, between 104-5.

${ }^{110}$ Barbot, Barbot, 235-7; Barbot, Description, 98 plate B, 106-7, 122; Dapper, Naukeurige Beschrijvinge, 383; Jones, "Kquoja Kingdom."

${ }^{111}$ Donelha, Descrição, p. 75; Rodney, Upper Guinea Coast, 52-3; Alie, New History, 17-8. 
The English were the major European traders in this region, and had probably established a factory there during the $1620 \mathrm{~s} .{ }^{112}$ All of the witnesses agreed that, by 1648 , Wood had traded there for some twenty-five years; for at least fifteen years he had maintained a factory "called Berumony," employing his agent James Holder and others. ${ }^{113}$ Wood's allegation and witnesses claimed that Towa sold to Holder and Wood the same right of "letting hindering \& forbidding of trade traffique [and] commerce there as hee the said Towa had".114 The defendants denied this, claiming that trade was allowed to anyone. ${ }^{115}$

Whether a monopoly was sanctioned by Towa and his subjects or not, Wood had evidently maintained the "sole trade" there, and his own witnesses admitted that his aim was to exclude other traders, presumably within the Guinea Company monopoly. ${ }^{116}$ All of the witnesses on both sides, and Ireland himself, had previously worked for Wood and spent some time in Sherbro. ${ }^{117}$ Some of the witnesses had lived in Sherbro for over a decade and Wood had "of late [employed] a preaching Minister called Mr Calker," suggesting a fairly settled English presence. ${ }^{118}$ They may have married into the regional elite, as later English merchants did. ${ }^{119}$ There are some indications, too, that Wood's position was yet to realise a profit. Wood and his witnesses estimated that the factory cost him $£ 6-800$ annually, and that he had sent out

\footnotetext{
${ }^{112}$ Blake, "English Trade," 330; see Dapper, Naukeurige Beschrijvinge, 383; Barbot, Description, 107.

${ }^{113}$ Quoting TNA HCA 13/61, 104r; cf. 103v, 106v-7r, 118v, 119v; TNA HCA 23/108/232.

On Europeans resident in this region of Africa, see Da Silva, "Cross-Cultural Entrepreneurship," 67.

114 TNA HCA 24/108/232; 103v, 106r-v, 118v, 119v.

115 TNA HCA 13/121, no folio numbers, answers of Henry Futter, Thomas Cust, and George Ireland, [29-30 June 1648].

116 TNA HCA 23/15/182; HCA 13/61, 119r, 120v.

117 TNA HCA 23/15/182; HCA 13/61, 103v, 104v-5v, 106r, 107r-v, 108v, 109r-v, 119r-v, 122 r.

118 TNA HCA 13/61, 103v-4r, 106v, 118r-v, 119v, 121r, $122 \mathrm{v}$.

119 Thornton, Cultural History, 260.
} 
"rich cargazons," some worth over $£ 1,000$, but much of the proceeds remained in "reddwood" in Sherbro. ${ }^{120}$

Ireland's aim was to break into this scene. He had led voyages before in which he attempted to trade for himself, but was prevented by Holder. ${ }^{121}$ Ireland apparently reserved a special grudge for Holder: Michael Woodcocke, one of Wood's witnesses, deposed that he heard Ireland say "hee intended to goe to Cerbero... because (as hee said) the Scab Holder... should knowe, that another could doe asmuch there as him." ${ }^{122}$ The defendants accused Woodcocke, who had commanded one of their former voyages, of being suborned during that voyage by Holder, which Woodcocke denied even though he had subsequently entered Wood's employment. ${ }^{123}$ Ireland's witnesses had crossed the other way, previously working for Wood but joining Ireland on his 1647 voyage.

Late in that year Ireland arrived with the Releife at Sierra Leone, and at the same time a pinnace, the George, commanded by George Francke, sailed to Sherbro. ${ }^{124}$ A number of witnesses noted that ships could travel up the river as far as "Limberman," but the area where camwood was purchased, and where the factory lay, was variously described as 50 to 100 miles upriver from there. ${ }^{125}$ They also implied that, while Wood's goods were gathered into his factory, his "servants" were spread across the region. Francke, along with Robert Meriton and

120 TNA HCA 13/61, 105r, 107r-v.

${ }^{121}$ Ibid., 105v, 107v, 109r-v.

${ }^{122}$ Quoting TNA HCA 13/61, 123r, cf. 104v; TNA HCA 24/108/232.

123 TNA HCA 23/15/182; HCA 13/61, 123v; on this former voyage see HCA 24/108/215; HCA 13/120, no folio numbers, answer of Michael Woodcocke, 18 September 1647. 124 TNA HCA 23/15/182; HCA 24/108/247; HCA 13/61, 103r-v, 104r, 105r-6r, 118v-9r, $120 \mathrm{r}, 121 \mathrm{v}$. Using smaller coasting vessels in combination with larger ships was the usual approach to trade in the region: Davies, Royal African Company, 217-8, 229; Silva, Dutch and Portuguese, 178-80.

125 TNA HCA 24/108/247; HCA 13/61, 105r, 107v, 109r, 119r, 120v, 122r, 123r. Rodney located "Limberman" on Sherbro Island (Upper Guinea Coast, 159), but it seems more likely to be Gbamani, appearing on the Newcomb map as "Bahmanne," approximately ten miles downriver from Tormabum (Cyclopedia of Missions, between 104-5). For contemporary descriptions of the rivers, see Barbot, Barbot, 236-7; Barbot, Description, 106-7. 
John Drowne, "went up into the country to buy redd wood."126 Holder was reportedly angered by this: he not only "hindered" their efforts himself, he complained to Towa. ${ }^{127}$ Francke (rather curiously, given his vested interest in challenging Holder's claims) admitted that Towa told Holder "the said Rivers and streames were his and that hee had bought and paid for them... and therefore willed him to doe what hee would to the company of the said Pinnace."128 Another witness deposed that Towa "came downe and discharged them from trading there."129 Apparently this decision was not accepted by everyone. Francke claimed that "the Natives and Inhabitants of that countrey did for the most part love and affect... James Holder," but "hee heard diverse of the Natives speake very much against... Holder." 130 John Crafford, master's mate of the Releife, opined that "the Natives... did well love and affect [Wood's] servants and factors," but pointedly added "saving the said Holder."131 It seems, then, that some in the region were opposed to Wood's monopoly, and that Francke and his companions appealed to them. Wood and his witnesses claimed that Ireland's men "did indeavour to incense the Negroes against... James Holder."132

This led initially to a confrontation between the agents of the English competitors. Francke and Drowne reportedly said "Holder had wronged the countrey and kept them as his slaves in making them take what goods hee pleased," and that they "could have him kickt off the bank when they pleased." 133 Woodcocke, who was present at "Limberman" in the James, deposed that he heard Holder "complaine of some disgracefull words used against him by...

\footnotetext{
126 TNA HCA 13/61, 103r-v

${ }^{127}$ Ibid., 104v, 107r, 118r-v, 119v, 121r.

128 Ibid., $104 \mathrm{v}$.

${ }^{129}$ Ibid., 118v-9r.

${ }^{130}$ Ibid., $104 \mathrm{v}$.

${ }^{131}$ Ibid., $108 \mathrm{v}$.

132 TNA HCA 24/109/247; HCA 13/61, 120r, $121 \mathrm{v}$.

133 TNA HCA 13/61, 118v-9r, 120v, 123r-v. A later ruler halted trade with the English in 1679 and demanded that prices be "reduced to what they were in Mr Wood's time": Rodney, Upper Guinea Coast, 165.
} 
Franck, and bidd [Richard] Cloud goe ashore and aske [Franke] the reason thereof, and if hee give noe satisfaction, to give him a cutt on the eare." 134 Woodcocke and other witnesses reported that Cloud subsequently came aboard again "with his head all broken and bloody," so Francke clearly did not give "satisfaction," and Woodcocke and the James departed soon after. $^{135}$

The Releife then arrived in Sherbro at some point before March 1648, coinciding with (or precipitating) a local crisis, although Ireland and his associates maintained that they had purchased all of their cargo before the subsequent outbreak of violence. ${ }^{136}$ According to John Drowne, on Easter Monday James Holder, "a young boy" called John Charles, and "a negro belonging to Wood" were attacked and killed. Soon after, the factory was assaulted and goods were seized; the "preaching minister" escaped the factory "in shirt breeches and stockings."137 George Francke claimed to have seen the attack on Holder, "on shore in a place called Boome, neere unto a river soe called." It began with the assailants shooting

many arrowes at... Holder, and the said youth and Negro as they were passinge in the said River in a boate... Holder perceiving himselfe to be in such danger, and thinking... by going ashore to appease them... assoone as they landed the said Negroes presently killed the youth and Negro with an iron Instrument or weapon which they use to carry in their hands and kill their elephants therewith, and having seized... Holder and bound his hands, after they had danced a little about him they knocked him on the head with two pestalls on sticks and soe killed him. ${ }^{138}$

\footnotetext{
134 TNA HCA $13 / 61,123 \mathrm{v}$.

135 TNA HCA 24/108/232; HCA 13/61, 120r, 122r, 123r.

136 TNA HCA 24/108/232; HCA 23/15/182; HCA 13/61, fos 105v, 107v, 119v-20r. Barbot wrote that April and May were the best time to travel upriver and trade: Barbot, Barbot, 2367; Barbot, Description, 106-7.

${ }^{137}$ Quoting TNA HCA 13/61, 104r-v; cf. 106v, 108v, 120v; HCA 13/121, no folio numbers, answer of Henry Futter, Thomas Cust, and George Ireland, [29-30 June 1648] and 30 June 1648; HCA 24/108/232.

138 TNA HCA 13/61, 104r.
} 
This is a heavily stylised description, and perhaps Francke emphasised some aspects of the attack to make it seem strange to his audience, to remove himself and the defendants from any suggestion of complicity. However, José Nafafé has emphasised the importance of recognising "how perceived self-interests were interwoven with rituals and beliefs in the creation of an Atlantic space in Western Africa," and this episode may represent a moment in which Atlantic commerce connected with indigenous ritual practices, even if the evidence is too opaque for more sustained analysis. ${ }^{139}$

Wood, for his part, had no doubt that Ireland and his companions were involved. Wood claimed — and Ireland's witnesses acknowledged — that Ireland had forbidden them to carry any letters home, suggesting he wanted to prevent reports returning to England. ${ }^{140}$ Wood maintained that some of the camwood brought to England in the Releife had been stolen out of his factory. ${ }^{141}$ Richard Howtinge, who had been aboard the James at "Limberman," deposed that, in June 1648, he met Ireland "upon the Exchange shortly after his arrival [in London]... and asking him... howe doe all our friends in Cerbero... Ireland answered saying, Mr Holder and I are good friends nowe, and this deponent saying hee was glad to heare it... Ireland replied, yes, wee are nowe good friends, for the Negroes have knocked him... o'th head, and John Charles with him... and the Negroes had taken away their goods, and either had knockt Dick Cloud... o'th head, or would knock him on the head."142

This evidence suggests a delicate and volatile situation in which factions amongst both Africans and Europeans aligned with and confronted one another, although it is difficult to know, from this evidence, on exactly what terms the contact between these factions took place. The long residence of some English factors, and Holder's appeal to Towa, suggests a degree

\footnotetext{
139 Nafafé, “African voice," 73.

140 TNA HCA $13 / 61,104 \mathrm{v}, 108 \mathrm{v}$.

141 TNA HCA 24/108/232.

142 TNA HCA $13 / 61,120$ r.
} 
of familiarity had developed, but at the same time there was clearly the potential for violent confrontation, probably increased, as at Portudal, by difficulties in communication and cultural misunderstandings.

Wood apparently possessed a written deed confirming his purchase, but the defendants described the inhabitants of Sherbro as "Negroes \& heathens \& such whoe cannot write or reade att least not understand our English writings... for a bottle [of] wine or strong water or some other trifle [they will] signe or putt their hands to any thing... and when they haue done will not performe any thing of it." ${ }^{143}$ Most of the witnesses acknowledged the absence of literacy, although none of them responded to the rest of this interrogatory. ${ }^{144}$ It is not an especially edifying or perceptive commentary, but it highlights the possibility that what Wood and Holder thought they had "bought and paid for" was not necessarily what Towa and his subjects thought that they had sold, if indeed they perceived the situation as a transaction in this manner. ${ }^{145}$ In the plaintiffs' allegation, it was asserted that the "Negroes and heathens" who possessed these lands, and the right to control trade in them, did so "de iure gentium."146 This might be seen as extending to Towa's realm the recognition of a "state" in European terms, but it also represents a form of legal encroachment, ignoring indigenous perceptions of politics and possession (including Towa's possible status as subordinate to other powers) in a fashion which conveniently suited Wood's claim to a monopoly, but which may have provoked opposition in Sherbro. ${ }^{147}$ As in Portudal, even regular trade and some familiarity between the

143 TNA HCA 24/108/232; HCA 13/61, 121r; HCA 23/15/182.

144 TNA HCA 13/61, 119r, 120v, 122r.

${ }^{145}$ On the contrast between European and African concepts of landholding in particular, see Daaku, Trade and Politics, ch. 3; Elbl, "Cross-Cultural Trade," 175-7, 189; Thornton, Africa and Africans, 74-6; Perreault, Early English Encounters, 138-54.

146 TNA HCA 24/108/232.

${ }^{147}$ For discussion of these issues, see Mancke, "European Expansion"; Mancke, "Oceanic Space"; Benton, Search for Sovereignty. 
trading partners did not foreclose the possibility of violence erupting, ignited by the combination of internal rivalries between both African and European traders.

\section{Conclusion}

There are limits to what these lawsuits reveal; most obviously, they tell us little about the African perspectives of these events, although it is clear that in these commercial relationships it was the indigenous partners who largely made the running, which most scholars now agree was true of Atlantic Africa in general. ${ }^{148}$ Trade occurred only with the permission of and under the terms set by African rulers, as appears quite clearly in the first case study by the attack on Cawson, and in the second by Towa's support for Wood. However, Cawson's attempt to impose his own rules and the ultimately fatal hostility towards Holder also highlight the complex constellations of African and European interests which made these cross-cultural interactions unpredictable and prone to violence. This was compounded by ignorance or incomprehension - if British merchants and sailors recognised some distinctions of status within African societies, as P. E. H. Hair and April Lee Hatfield have argued, their understanding still did not go very deep, even, as in the second case, after years of residence. ${ }^{149}$

While British traders' activity on the West African coast was subject to circumstances beyond their control, this activity was also part of networks which they did seek to control, with impacts on all sides of the Atlantic. In this respect it is comparable to the Dutch model of diffuse empire outlined by Filipa Ribeiro da Silva: a series of trading posts initially focussed on a direct Europe-Africa commerce in material commodities, but shifting over the seventeenth

\footnotetext{
148 Thornton, Africa and Africans, 38; Law, "Here is no Resisting the Country"; Morgan, "Africa and the Atlantic," 226-9; Traoré, "State Control"; Northrup "Africans, Early European Contact"; Havik and Green, "Brokerage"; Nafafé, "African Voice". ${ }^{149}$ Hair, "Attitudes”; Hatfield, "“Very Wary People." See also MacGaffey, "Dialogues."
} 
century towards ever deeper involvement in the transatlantic slave trade. ${ }^{150}$ Although by the 1640s the British presence in West Africa was smaller and even less coordinated than the Dutch, a trading network existed which Wood and Wilson sought to protect from their rivals, apparently without much success. The Sherbro case reflects the growth of British factory-trade in West Africa; the Portudal case reveals the influence of the Atlantic context and the new assumptions which emerged from it, and which were shaped by actions in Africa as well as elsewhere around the oceanic basin. Both cases also show how the British, like other European nations, resorted to their own concepts of maritime and commercial law even in places where they could not necessarily impose them.

The question of law and the comparison with the Dutch also suggests another way in which West Africa figured in the British Atlantic: as a theatre for imperial claims and confrontations. One early cornerstone of British imperial policy were the Navigation Acts, the first of which, passed in 1651, was aimed directly against the Dutch. ${ }^{151}$ This Act was preceded by a parliamentary ordinance of January 1647 forbidding Atlantic colonies to trade with foreign ships. ${ }^{152}$ The assembly of Virginia protested that this was "on purpose to affright \& expel the Dutch... [prompted] by the wylie \& spetious pretences of Merchants, or Seamen tradeing to the Colony," and they were right. ${ }^{153}$ In July 1646 a group of shipmasters and merchants testified in the admiralty court in response to interrogatories submitted by William Allen, which complained that the Dutch refused to let English ships trade at any of their colonies, while themselves regularly trading at English plantations. ${ }^{154}$ Some of Allen's own goods had been

\footnotetext{
${ }^{150}$ Silva, "Dutch trade"; Silva, Dutch and Portuguese, 28-38, 46-55, 69-82, 98-107, 295303 ,

${ }^{151}$ Farnell, "The Navigation Act"; Groenveld, "The English Civil Wars."

152 Parliament, Die Sabbathi 23 Ianuari 1646.

${ }^{153}$ Billings, The Papers of Sir William Berkeley, 75-6.

154 TNA HCA 23/15/77; HCA 13/60, depositions of Samuel Leigh, Robert Shapton, Francis Crower, and John Maxwell, 7 July 1646, fos 636v-9r, Aaron Williams, 8 July 1646, fos 639rv, Thomas Stagg and Arthur Bayly, 9 July 1646, fos 640v-1r, and George Goutton, Jerman Honychurch, John Darell, George Ireland, and Thomas Batson, fos 626r-8v.
} 
impounded at Middleburg, possibly in retaliation to the seizure of a Dutch vessel by a London ship in a sequence of events linked to the Kent Island venture with which I began, and this may have provided Allen's motivation for protesting against the Dutch. ${ }^{155}$

Amongst these witnesses were Robert Shapton and George Ireland, both of whom explicitly referred to trade with Africa and the Americas, while others discussed the Indian Ocean. To these shipmasters and merchants, appealing to the British government for greater control of trade, Africa was evidently an essential part of the system as a whole, a view the government endorsed: during the 1660s, commerce-raiding in West Africa provoked the Second Anglo-Dutch War. ${ }^{156}$ British attempts to control the Atlantic world-nascent and limited though these were in the mid-seventeenth century-developed from the experiences of merchants and seafarers, an interplay of cooperation and violent competition which, as these two lawsuits reveal, were characteristic of early modern West Africa and indeed the Atlantic as a whole.

155 TNA HCA 3/42, 238r, 250r, 255r, 257r, 259r, 262r, 267r, 268v, 270v, 289v; HCA 24/108/37; see the sources cited in n. 1 .

${ }^{156}$ Jones, Anglo-Dutch Wars, 145-50. 


\section{Bibliography}

\section{Unpublished Material}

The National Archives, Kew, United Kingdom. Records of the High Court of Admiralty and Colonial Vice-Admiralty Courts. TNA HCA.

\section{Published Sources}

Alie, Joe A. D. A New History of Sierra Leone. Basingstoke: MacMillan, 1990.

Almada, André Álvares de. An Interim and Makeshift Edition of André Álvarez de Almada's Brief Treatise on the Rivers of Guinea, translated by P. E. H. Hair. Liverpool: University of Liverpool, 1984.

Alsop, J. D. "Sea Surgeons, Health and England's Maritime Expansion: The West African Trade 1553-1660.” Mariner's Mirror 76 (1990): 215-21.

. "The Career of William Towerson, Guinea Trader." International Journal of Maritime History 4 (1994): 45-82.

—. "Tudor Merchant Seafarers in the Early Guinea Trade." In The Social History of English Seamen, 1485-1649, edited by Cheryl A. Fury, 75-115. Woodbridge: Boydell and Brewer, 2012.

Andrade, Tonio. "A Chinese Farmer, Two African Boys, and a Warlord: Towards a Global Microhistory." Journal of World History 21 (2010): 573-91.

Andrews, Kenneth R. Trade, Plunder, and Settlement: Maritime Enterprise and the Genesis of the British Empire, 1480-1630. Cambridge: Cambridge University Press, 1984.

Antunes, Cátia, and Filipa Ribeiro da Silva. "Cross-Cultural Entrepreneurship in the Atlantic: Africans, Dutch and Sephardic Jews in Western Africa, 1580-1674." Itinerario 35 (2011): $49-76$.

Appleby, John C. "A Guinea Venture, c. 1657: A Note on the Early English Slave Trade." Mariner's Mirror 79 (1993): 84-7. 
__. "A Business of Much Difficulty”: A London Slaving Venture 1651-1654.” Mariner's Mirror 81 (1995): 3-14.

—. "Vassall, Samuel (bap. 1586, d. 1667)." In Oxford Dictionary of National Biography, edited by H. C. G. Matthew and Brian Harrison. Oxford: Oxford University Press, 2004. Armitage, David, and Michael J. Braddick. The British Atlantic World, 1500-1800. Basingstoke: Palgrave, 2002.

Ashton, Robert. "Crisp, Sir Nicholas, first baronet (c. 1599-1666).” In Oxford Dictionary of National Biography, edited by H. C. G. Matthew and Brian Harrison. Oxford: Oxford University Press, 2004.

Barbot, Jean. A Description of the Coasts of North and South-Guinea. London, 1732.

- Barbot on Guinea: The Writings of Jean Barbot on West Africa, 1678-1712, edited by P. E. H. Hair, Adam Jones, and Robin Law. London: The Hakluyt Society, 1992.

Barry, Boubacar. Le Royaume du Waalo: Le Sénégal avant la Conquête. Paris: Éditions Karthala, 1972, reprinted 1985.

——. La Sénégambie du XVe au XIXe Siècle: Traite Négière, Islam et Conquête Coloniale. Paris: Éditions L’Harmattan, 1988.

Benjamin, Thomas. The Atlantic World: Europeans, Africans, Indians and their Shared History, 1400-1900. Cambridge: Cambridge University Press, 2009.

Benton, Lauren. "Legal Spaces of Empire: Piracy and the Origins of Ocean Regionalism." Comparative Studies in Society and History 47 (2005): 700-724.

-. A Search for Sovereignty: Law and Geography in European Empires, 1400-1900. Cambridge: Cambridge University Press, 2009.

Blake, J. W. "English Trade with the Portuguese Empire in West Africa, 1581-1629." Congresso do Mundo Português 6 (1940): 313-41. -, ed. Europeans in West Africa, 1450-1560. London: The Hakluyt Society, 1942. 
—. "The English Guinea Company, 1618-1660." Proceedings of the Belfast Natural History and Philosophical Society 2/3 (1945-6): 14-27.

—. "The Farm of the Guinea Company in 1631". In Essays in British and Irish history in Honour of James Eadie Todd, edited by H. A. Crone, T. W. Moody, and D. B. Quinn, 86106. London: F. Muller, 1949.

—. West Africa: Quest for God and Gold, 1454-1578. London: Curzon Press, 1977.

Blakemore, Richard J. "London and the Thames Maritime Community during the British Civil Wars, 1640-1649.” Unpublished PhD Thesis, University of Cambridge: 2013.

—. "The Politics of Piracy in the Revolutionary Atlantic, c. 1640-1649." International Journal of Maritime History 25 (2013): 159-72.

—. "The Legal World of English Sailors, c. 1575-1729." In Law, Labour, and Empire: Comparative Perspectives on Seafarers, c. 1500-1800, edited by Maria Fusaro, Bernard Allaire, Richard Blakemore and Tijl Vanneste, 100-120. Basingstoke: Palgrave MacMillan, 2015.

—. "Orality and Mutiny: Authority and Speech amongst the Seafarers of Early Modern London.” In Spoken Word and Social Practice: Orality in Europe (1400-1700), edited by Thomas Cohen and Lesley Twomey, 250-75. Leiden: Brill, 2015.

Bliss, Robert M. Revolution and Empire: English Politics and the American Colonies in the Seventeenth Century. Manchester: Manchester University Press, 1990.

Boelhower, William. “'I'll Teach You How to Flow': On Figuring out Atlantic Studies.” Atlantic Studies 1 (2004): 28-48.

Boogaart, Ernst van den. "The Trade between Western Africa and the Atlantic World, 160090: Estimates of Trends in Composition and Value.” Journal of African History, 33 (1992): $369-85$. 
Boulègue, Jean. Les Luso-Africains de Sénégambie. Lisbon: Instituto de Inverstigação Científica Tropical, 1989.

—. Les Royaumes Wolof dans l'Espace Sénégambien (XIIIe-XVIIIe Siècle). Paris: Éditions Karthala, 2013.

Bowen, H. V., Elizabeth Mancke, and John G. Reid, eds. Britain's Oceanic Empire: Atlantic and Indian Ocean Worlds, c. 1550-1850. Cambridge: Cambridge University Press, 2012.

Brenner, Robert. Merchants and Revolution: Commercial Change, Political Conflict, and London's Overseas Traders, 1550-1653. Cambridge: Cambridge University Press, 1993.

Broecke, Pieter van den. Pieter van den Broecke's Journal of Voyages to Cape Verde, Guinea and Angola (1605-1612), edited and translated by J. D. La Fleur. London: The Hakluyt Society, 2000.

Brooks, George E. Eurafricans in West Africa: Commerce, Social Status, Gender, and Religious Observance from the Sixteenth to the Eighteenth Century. Oxford: James Currey, 2003.

Burnard, Trevor. "The British Atlantic.” In Atlantic History: A Critical Appraisal, edited by Jack P. Greene and Philip D. Morgan, 111-37. Oxford: Oxford University Press, 2009.

. "The Atlantic Slave Trade." In The Routledge History of Slavery, edited by Gad Heuman and Trevor Burnard, 80-97. London: Routledge, 2011.

Chambers, Douglas B. “The Black Atlantic: Theory, Method, and Practice.” In The Atlantic World, 1450-2000, edited by Toyin Falola and Kevin D. Roberts, 151-73. Bloomington: Indiana University Press, 2008.

Chaplin Joyce E. “The British Atlantic.” In The Oxford Handbook of the Atlantic World, edited by Nicholas Canny and Jack P. Greene, 219-34. Oxford: Oxford University Press, 2011. Charles I. By the King. A Proclamation Concerning the Trade of Ginney. London, 1631. 
Chouin, Gérard. "Vu, Dit ou Déduit? L'étude des Relations de Voyage en Guinée.” Journal des Africanistes, 75 (2005): 97-101.

Coelho, Francisco de Lemos. Description of the Coast of Guinea (1684), translated by P. E. H. Hair. Liverpool: University of Liverpool, 1985.

Curtin, Philip. Economic Change in Precolonial West Africa: Senegambia in the Era of the Slave Trade. Madison WI: University of Wisconsin Press, 1975.

. Cross-Cultural Trade in World History. Cambridge: Cambridge University Press, 1984

Daaku, Kwame Yeboa, Trade and Politics on the Gold Coast 1600-1720. Oxford: Oxford University Press, 1970.

Dapper, Olfert. Naukeurige Beschrijvinge der Afrikaensche Gewesten. Amsterdam, 1668.

Davidson, Basil, West Africa before the Colonial Era: A History to 1850. London: Longman, 1998.

Davies, K. G. The Royal African Company. London: Longman, 1957.

D’Avity, Pierre. Description Generale de l'Afrique. Paris, 1637.

Disney, A. R. A History of Portugal and the Portuguese Empire. 2 vols. Cambridge: Cambridge University Press, 2009.

Donelha, André. Descrição da Serra Leoa e Dos Rios de Guiné do Cabo Verdo (1625), edited by Aveliona Teixera da Mota, translated by P. E. H. Hair. Lisbon: Investigações Científicas do Ultramar, 1977.

Ebert, Christopher. "European Competition and Cooperation in Pre-Modern Globalization: 'Portuguese' West and Central Africa, 1500-1600.” African Economic History 36 (2008): $53-78$.

Elbl, Ivana. "Cross-Cultural Trade and Diplomacy: Portuguese Relations with West Africa, 1441-1521.” Journal of World History 3 (1992): 165-204. 
Eltis, David. "The Volume and Structure of the Transatlantic Slave Trade: A Reassessment." William and Mary Quarterly 58 (2001): 17-46.

- "Africa, Slavery, and the Slave Trade, Mid-Seventeenth to Mid-Eighteenth Centuries." The Oxford Handbook of the Atlantic World, edited by Nicholas Canny and Jack P. Greene, 271-86. Oxford: Oxford University Press, 2011.

Eltis, David, and David Richardson. "A New Assessment of the Transatlantic Slave Trade." In Extending the Frontiers: Essays on the New Transatlantic Slave Trade Database, edited by Davis Eltis and David Richardson, 1-60. New Haven: Yale University Press, 2008.

Farnell, J. E. "The Navigation Act of 1651, the First Dutch War, and the London Merchant Community.” Economic History Review 16 (1963-4): 439-54.

Farrar, Tarikhu. "When African Kings Became 'Chiefs': Some Transformations in European Perceptions of West African Civilization, c. 1450-1800.” Journal of Black Studies 23 (1992): 258-78.

Feinberg, Harvey M. "Africans and Europeans in West Africa: Elminans and Dutchmen on the Gold Coast during the Eighteenth Century." Transactions of the American Philosophical Society 79 (1989): 1-186.

Forbes, Allyn Bailey, ed. Winthrop Papers. 6 vols. Boston, Massachusetts: Massachusetts Historical Society, 1929-1992.

Fyfe, Christopher. Sierra Leone Inheritance. London: Oxford University Press, 1964.

Games, Alison. “'The Sanctuarye of Our Rebell Negroes': The Atlantic Context of Local Resistance on Providence Island, 1630-41.” Slavery and Abolition 19 (1998): 1-21.

Ghobriel, John-Paul. "The Secret Life of Elias of Babylon and the Uses of Global Microhistory." Past and Present, 222 (2014): 51-93.

Gilroy, Paul, The Black Atlantic: Modernity and Double Consciousness. Cambridge, Massachusetts: Harvard University Press, 1993. 
Ginzburg, Carlo, "Latitude, Slaves, and the Bible: An Experiment in Microhistory." Critical Inquiry 31 (2005): 665-83.

Gould, Eliga H. “Zones of Law, Zones of Violence: The Legal Geography of the British Atlantic, circa 1772." William and Mary Quarterly, 60 (2003): 471-510.

—. "Lines of Plunder or Crucible of Modernity? The Legal Geography of the EnglishSpeaking Atlantic, 1660-1825.” In Seascapes: Maritime Histories, Littoral Cultures, and Transoceanic Exchanges, edited by Jerry H. Bentley, Renate Bridenthal, and Kären Wigen, 105-20. Honolulu: University of Hawai‘i Press, 2007.

Gragg, Larry. ““To Procure Negroes”: The English Slave Trade to Barbados, 1627-60.” Slavery and Abolition 16 (1995): 65-84.

Green, Tobias. "Further Considerations on the Sephardim of the Petit Côte." History in Africa 32 (2005): 165-83.

—. "Building Creole Identity in the African Atlantic: Boundaries of Race and Religion in Seventeenth Century Cabo Verde.” History in Africa 36 (2009): 103-25.

Groenwald, Simon. "The English Civil Wars as a Cause of the First Anglo-Dutch War, 16501652.” Historical Journal 30 (1987): 541-66.

Hair, P. E. H. “An Ethnolinguistic Inventory of Upper Guinea before 1700.” African Language Review 6 (1967): 32-70.

—_. "Protestants as Pirates, Slavers, and Protomissionaries: Sierra Leone 1568 and 1582." Journal of Ecclesiastical History 3 (1970): 203-224.

—_. "Barbot, Dapper, Davity: A Critique of Sources on Sierra Leone and Cape Mount." History in Africa 1 (1974): 25-54.

—. "Hamlet in an Afro-Portuguese Setting: New Perspectives on Sierra Leone in 1607." History in Africa 5 (1978): 21-42.

—_. "On Editing Barbot." History in Africa 20 (1993): 52-9. 
—. "The Early Sources on Guinea." History in Africa 21 (1994): 87-126.

—. "The Experience of the Sixteenth-Century English Voyages to Guinea." Mariner's Mirror 83 (1997): 3-13.

—. "Attitudes to Africans in English Primary Sources on Guinea up to 1650." History in Africa 26 (1999): 43-68.

and J. D. Alsop. English Seamen and Traders in Guinea, 1553-1565: The New Evidence of their Wills. Lampeter: Edwin Mellen, 1992.

Hair, P. E. H., and Robin Law. “The English in Western Africa to 1700.” In The Oxford History of the British Empire, vol. 1. The Origins of Empire: British Overseas Enterprise to the Close of the Seventeenth Century, edited by Nicholas Canny, 241-63. Oxford: Oxford University Press, 1998.

Hakluyt, Richard. The Principal Nauigations, Voyages, Traffiques and Discoueries of the English Nation. 3 vols. London, 1599-1600.

Hatfield, April Lee. “A 'Very Wary People in their Bargaining' or 'Very Good Merchandise': English Traders' Views of Free and Enslaved Africans, 1550-1650." Slavery and Abolition 25 (2004): 1-17.

Havik, Philip J., and Toby Green. "Introduction: Brokerage and the Role of Western Africa in the Atlantic World." In Brokers of Changes: Atlantic Commerce and Cultures in PreColonial Western Africa, edited by Toby Green, 1-27. Oxford: Oxford University Press.

Heywood, Colin. "The English in the Mediterranean, 1600-1630: A Post-Braudelian Perspective on the "Northern Invasion." In Trade and Cultural Exchange in the Early Modern Mediterranean: Braudel's Maritime Legacy, edited by Maria Fusaro, Colin Heywood, and Mohamed-Salah Omri, 23-44. London: IB Tauris, 2010. 
Horta, José da Silva. "Evidence for a Luso-African Identity in 'Portuguese' Accounts on 'Guinea of Cape Verde' (Sixteenth-Seventeenth Centuries).” History in Africa 27 (2000): 99-130.

Hosmer, James Kendall, ed. Winthrop's Journal 'History of New England,' 1630-1649. 2 vols. New York: C. Scribner's sons, 1908.

Inikori, Joseph E. “Africa and the Globalization Process: Western Africa, 1450-1850.” Journal of Global History 2 (2007): 63-86.

Jacobs, Bart. "The Dutch in Seventeenth-Century Senegambia and the Emergence of Papiamentu." In Brokers of Change: Atlantic Commerce and Cultures in Pre-Colonial Western Africa, edited by Toby Green, 193-217. Oxford: Oxford University Press, 2012. Jannequin, Claude. Voyage de Lybie av Royavme de Senega. Paris, 1643.

Jenkinson, Hilary. "The Records of the English African Companies." Transactions of the Royal Historical Society 6 (1912): 185-220.

Jones, Adam. "The Kquoja Kingdom: A Forest State in Seventeenth Century West Africa." Paideuma 29 (1983): 23-43.

—. Raw, Medium, Well Done: A Critical Review of Editorial and Quasi-Editorial Work on Pre-1885 European Sources for Sub-Saharan Africa, 1960-1986. Madison WI: University of Wisconsin, 1987.

—. "Decompiling Dapper: A Preliminary Search for Evidence." History in Africa 17 (1990): 171-209.

Jones, Adam, and Beatrix Heintze. "Introduction." In European Sources for Sub-Saharan Africa before 1900: Use and Abuse, edited by Adam Jones and Beatrix Heintze, 1-17. Stuttgart: Franz Steiner Verlag, 1987.

Jones, J. R. The Anglo-Dutch Wars of the Seventeenth Century. London: Longman, 1996. 
Kea, Ray A. Settlements, Trade and Politics in the Seventeenth Century Gold Coast. Baltimore: John Hopkins University Press, 1982.

Kelsey, Sean. "Rich, Robert, second earl of Warwick (1587-1658)." In Oxford Dictionary of National Biography, edited by H. C. G. Matthew and Brian Harrison. Oxford: Oxford University Press, 2004.

Křížová, Markéta. "Frontiers of Race, Frontiers of Freedom: The Fabrication of the "Negro Slave' in Early Modern European Discourse." In Imagining Frontiers, Contesting Identities, edited by Steven G. Ellis and Lud'a Klusáková, 110-23. Pisa: Pisa University Press, 2007.

Law, Robin. “'Here is No Resisting the Country.' The Realities of Power in Afro-European Relations on the West African 'Slave Coast.'” Itinerario 18 (1994): 50-64. . "The First Scottish Guinea Company, 1634-9.” Scottish Historical Review 76 (1997): 195-202. , ed. The Local Correspondence of the Royal African Company of England, 1681-1699. 3 vols. Oxford: Oxford University Press, 1997-2006.

—. "Africa in the Atlantic World, c.1760-c.1840." In The Oxford Handbook of the Atlantic World: 1450-1850, edited by Nicholas Canny and Philip Morgan, 586-601. Oxford: Oxford University Press, 2011.

Law, Robin, and Kristinn Mann. "West Africa and the Atlantic Community: The Case of the Slave Coast.” William and Mary Quarterly 56 (1999): 307-34.

Lawrence, A. W. Trade Castles and Forts of West Africa. London: Cape, 1963. Le Maire, Jacques-Joseph. Les Voyages du Sieur Le Maire. Paris, 1695. Levtzion, Nehemia. "North-West Africa: From the Maghrib to the Fringes of the Forest." In The Cambridge History of Africa. Volume 4, from c. 1600 to c. 1790, edited by Richard Gray, 142-222. Cambridge: Cambridge University Press, 1971. 
Lindley, Keith. "Wilson, Rowland (bap. 1613, d. 1650). In Oxford Dictionary of National Biography, edited by H. C. G. Matthew and Brian Harrison. Oxford: Oxford University Press, 2004.

Linebaugh, Peter and Marcus Rediker, The Many-Headed Hydra: Sailors, Slaves, Commoners, and the Hidden History of the Revolutionary Atlantic. London: Verso, 2000.

Lintingre, Pierre. "La Mission de Guinée au XVIIe Siècle.” Afrique Documents 97 (1968): 7797.

Lovejoy, Paul E. "The Upper Guinea Coast and the Transatlantic Slave Trade Database." African Economic History 38 (2010): 1-27.

and David Richardson. "The Business of Slaving: Pawnship in Western Africa, c. 1600-1810." Journal of African History 42 (2001): 67-89.

MacGaffey, Wyatt. "Dialogues of the Deaf: Europeans on the Atlantic Coast of Africa." In Implicit Understandings: Observing, Reporting, and Reflecting on Encounters between Europeans and Other Peoples in the Early Modern Era, edited by Stuart B. Schwartz, 24967. Cambridge: Cambridge University Press, 1994.

Makepeace, Margaret, "English Traders on the Guinea Coast, 1657-1668: An Analysis of the East India Company Archive.” History in Africa 16 (1989): 237-84.

Mancke, Elizabeth. "European Expansion and the Politicization of Oceanic Space." Geographic Review 89 (1999): 225-36.

—. "Oceanic Space and the Creation of a Global International System, 1450-1800." In Maritime History as World History, edited by Daniel Finamore, 149-66. Gainseville, Florida: University Press of Florida, 2004.

Mancke, Elizabeth, and Carole Shammas, eds. The Creation of the British Atlantic World. Baltimore: John Hopkins University Press, 2005. 
Marees, Pieter de. Beschryvinghe ende Historische Verhael van het Gout Koninckrijck van Guinea, edited by D. P. L’Honoré Naber. 's-Gravenhage: Martinus Nijhoff, 1912.

Mark, Peter. "The Evolution of 'Portuguese' Identity: Luso-Africans on the Upper Guinea Coast from the Sixteenth to the Early Nineteenth Century." Journal of African History 2 (1999): 173-91.

Mark, Peter, and José da Silva Horta. "Two Early Seventeenth-Century Sephardic Communities on Senegal's Petite Côte." History in Africa 31 (2004): 231-56.

. The Forgotten Diaspora: Jewish Communities in West Africa and the Making of the Atlantic World. Cambridge: Cambridge University Press, 2011.

Marsden, R. G., and Raphael Semmes. "Claiborne vs. Clobery et al in the High Court of Admiralty." Maryland Historical Magazine 26 (1931): 381-404. 27 (1932): 17-28, 99-114, 191-214, 337-52. 28 (1933): 26-43, 172-95, 257-65.

Mokyr, Joel, ed. The Oxford Encyclopedia of Economic History. Oxford: Oxford University Press, 2003.

Moody, Robert E., ed. The Saltonstall Papers, 1607-1815. 2 vols. Boston: Massachusetts Historical Society, 1972-1974.

Moraes, Nize Isabel de, ed. À la Découverte de la Petite Côte au XVIIe Siècle (Sénégal et Gambie). 4 vols. Dakar: Institut Fondemental d'Afrique Noire, 1993-8.

Morgan, Kenneth J. Slavery and the British Empire: From Africa to America. Oxford: Oxford University Press, 2007.

Morgan, Philip D. "Africa and the Atlantic, c. 1450 to c. 1820.” In Atlantic History: A Critical Appraisal, edited by Jack P. Greene and Philip D. Morgan, 223-48. Oxford: Oxford University Press, 2009. and Sean Hawkins, eds. Black Experience and the Empire. Oxford: Oxford University Press, 2006. 
Nafafé, José Lingna. "Challenges of the African Voice: Autonomy, Commerce, and Resistance in Precolonial Western Africa." In Brokers of Change: Atlantic Commerce and Cultures in Pre-Colonial Western Africa, edited by Toby Green, 71-88. Oxford: Oxford University Press, 2012.

Newcomb, Harvey. A Cyclopedia of Missions. London, 1856.

Newitt, Malyn, ed. The Portuguese in West Africa, 1416-1670: A Documentary History. Cambridge: Cambridge University Press, 2010.

Newson, Linda A. "Africans and Luso-Africans in the Portuguese Slave Trade on the Upper Guinea Coast in the Early Seventeenth Century.” Journal of African History, 53 (2012): 124.

Northrup, David. Africa's Discovery of Europe: 1450-1850. Oxford: Oxford University Press, 2002

—. "West Africans and the Atlantic, 1500-1800." In Black Experience and the Empire, edited by Philip D. Morgan and Sean Hawkins, 35-57. Oxford: Oxford University Press, 2006.

—. "Africans, Early European Contacts, and the Emergent Diaspora." In The Oxford Handbook of the Atlantic World: 1450-1850, edited by Nicholas Canny and Philip Morgan, 38-55. Oxford: Oxford University Press, 2011.

Ogborn, Miles. "Editorial: Atlantic Geographies." Social and Cultural Geography 6 (2005): $379-85$.

Ogborn, Miles. Global Lives: Britain and the World 1550-1800. Cambridge: Cambridge University Press, 2008.

Parliament. Die Sabbathi 23 Ianuarii 1646. Whereas the Severall Plantations in Virginia, Bermudas, Barbados and Other Places of America... London, 1647. 
Perreault, Melanie. Early English Encounters in Russia, West Africa and the Americas, 15301614. Lampeter: Edwin Mellen Press, 2004.

Pestana, Carla Gardina. The English Atlantic in an Age of Revolution, 1640-1661. Cambridge, Massachusetts: Harvard University Press, 2004.

Pettigrew, William. "Regulatory Inertia and National Economic Growth: An African Trade Case Study, 1660-1714.” In Regulating the British Economy, 1660-1850, edited by Perry Gauci, 25-40. Farnham: Ashgate, 2011.

Porter, R. "The Crispe Family and the African Trade in the Seventeenth Century." Journal of African History, 9 (1968): 57-77.

Putnam, Lara. "To Study the Fragments/Whole: Microhistory and the Atlantic World." Journal of Social History 3 (2006): 615-30.

Richardson, David. "Cultures of Exchange: Atlantic Africa in the Era of the Slave Trade." Transactions of the Royal Historical Society 19 (2009): 151-79.

Riordan, Timothy. The Plundering Time: Maryland and the English Civil War, 1645-1646. Baltimore: Maryland Historical Press, 2004.

Rodger, Nicholas. “The Law and Language of Private Naval Warfare.” Mariner's Mirror 100 (2014): 5-16.

Rodney, Walter. "Portuguese Attempts at Monopoly on the Upper Guinea Coast, 1580-1650." Journal of African History 6 (1965): 307-22.

Roper, L. H. "Charles I, Virginia, and the Idea of Atlantic History.” Itinerario 30 (2006): 3353.

"The Ties that Bound: The Conception of Anglo-America, 1617-67." Journal of Early American History 1 (2011): 142-66. 
Royal Commission on Historical Manuscripts, The Manuscripts of His Grace the Duke of Portland: Preserved at Welbeck Abbey. 10 vols. London: Eyre and Spottiswoode, 18911931.

Ruiters, Dierick. Toortse der Zee-vaert door Dierick Ruiters (1623), edited by S. P. L'Honoré Naber. 's-Gravenhage: Martinus Nijhoff, 1913.

Saint-Lô, Alexis de. Relation dv Voyage dv Cap-Verd. Paris, 1637.

Shurtleff, Nathaniel B., ed. Records of the Governor and Company of the Massachusetts Bay in New England. 6 vols. Boston, 1853-4.

Silva, Filipa Ribeiro da. Dutch and Portuguese in West Africa. Empires, Merchants and the Atlantic System, 1580-1674. Leiden: Brill, 2011.

—. "Dutch Trade with Senegambia, Guinea, and Cape Verde, c.1590-1674." In Brokers of Change: Atlantic Commerce and Cultures in Pre-Colonial Western Africa, edited by Toby Green, 125-49. Oxford: Oxford University Press, 2012.

Steckley, George F. "Instance Cases at Admiralty in 1657: A Court 'Packed up with Sutors." Journal of Legal History 7 (1986): 68-83.

—. "Litigious Mariners: Wage Cases in the Seventeenth-Century Admiralty Court." Historical Journal 42 (1999): 315-45.

Suret-Canale, S. “The Western Atlantic Coast 1600-1800.” In History of West Africa, edited by J. F. A. Ajayi and Michael Crowder, 387-440. London: Longman, 1971.

The Trans-Atlantic Slave Trade Database. URL: http://www.slavevoyages.org. Accessed 25 May 2015.

Thilmans, G. "Le Sénégal dans l'Evre d'Olfried Dapper.” Bulletin de l'Institut Fondemental d'Afrique Noire. Series B 33 (1971): 508-63.

Thornton, John. Africa and Africans in the Making of the Atlantic World. Cambridge: Cambridge University Press, 1992, second edition 1998. 
A Cultural History of the Atlantic World, 1250-1820. Cambridge: Cambridge University Press, 2012.

Traoré, Ousmane. "State Control and Regulation of Commerce on the Waterways and Coast of Senegambia, ca. 1500-1800," translated by Jeremy Rich. In Navigating African Maritime History, edited by Carina E. Ray, and Jeremy Rich, 57-80. St John's Newfoundland: International Maritime Economic History Association, 2009.

Trivellato, Francesca. "Is there a future for Italian Microhistory in the Age of Global History?" California Italian Studies 2 (2011). URL:

http://escholarship.org/uc/item/0z94n9hq. Accessed 25 May 2015.

Villault, Nicolas. Relation des Costes d'Afrique appelées Guinée. Paris, 1669.

Walvin, James. Crossings: Africa, the Americas and the Atlantic Slave Trade. London: Reaktion Books, 2013.

Wassenaer, Nicolaes van. Historisch Verhael alder Ghendenck-weerdichtse Geschiedenissen. 21 vols. Amsterdam, 1621-1635.

Yerxa, Donald A., ed. Recent Themes in the History of Africa and the Atlantic World: Historians in Conversation. Columbia SC: University of South Carolina Press, 2008. 